\title{
New Records of a Korean Species, Evarcha fasciata SEO, 1992 (Araneae: Salticidae) from Japan
}

\author{
Hiroyoshi IKEDA ${ }^{1)}$ and Shin-ichiro SAITO ${ }^{2)}$ \\ 池田博明1)・斎藤慎一郎 ${ }^{2)}$ : 韓国産の 1 種マミクロハエトリ \\ （クモ目：ハエトリグモ科）の日本からの記録

\begin{abstract}
Evarcha fasciata SEO, 1992 of the family Salticidae originally described from Korea is newly recorded from Japan. The female hitherto unknown is recognized based on the observations on mating behavior, and is described in detail.
\end{abstract}

Evarcha fasciata SEO, 1992 (Salticidae) was originally described on the basis of male specimens from Korea, and was also known from China (XIANJIN et al., 1993). The female of the species has not been known up to the present.

We examined many specimens of Japanese salticid spiders reported as Evarcha sp. (A) by CHIKUNI (1989) and found that they should be identified as Evarcha fasciata. The species will be described in the present paper based on comparison with a closely related species, Evarcha albaria (L. KoCH, 1878).

On the basis of the observations on mating behavior of this species, we recognized the pair of the species. The result of the observations will be reported in the present paper.

Some voucher specimens are deposited in the collection of the Department of Zoology, National Science Museum (Nat. Hist.), Tokyo.

The following abbreviations are used: ALE, anterior lateral eye; AME, anterior median eye; PLE, posterior lateral eye; PME, posterior median eye; RTA, retrolateral tibial apophysis. The distances between eyes are presented with a dash, e.g., ALE-ALE indicates distance between ALEs.

Evarcha fasciata SEO, 1992

(Figs. 1-5, 9-11)

Evarcha sp. (A): CHIKUNI, 1989, p. 153, fig. 30, p. 280.

Evarcha fasciata SEO, 1992, p. 159, figs. 1-5. XIANJIN, LIPING \& XIAOQUIN, 1993, pp. 69-71, figs. 196- 198. - XIANJIN, LIPING \& KIM, 1993, p. 9, figs. 9-11.

Specimens used for observations of mating. 1 का 1 subadult 우, Nakaikemi, Kashimagari, Tsuruga-shi, Fukui Pref., Japan, 27-IV-1996, 우 molted to adult on 22-VI

1) 1099, Kanade, Ashigarakami-gun, Oimachi, Kanagawa, 258-0018, Japan

干 258-0018 神奈川県足柄上郡大井町金手 1099

2) 29-5-2, B205, Komasu-cho, Fukui-shi, Fukui, 918-8218, Japan

干 918-8218 福井県福井市河増町 29-5-2, B205

Accepted November 26, 1997 

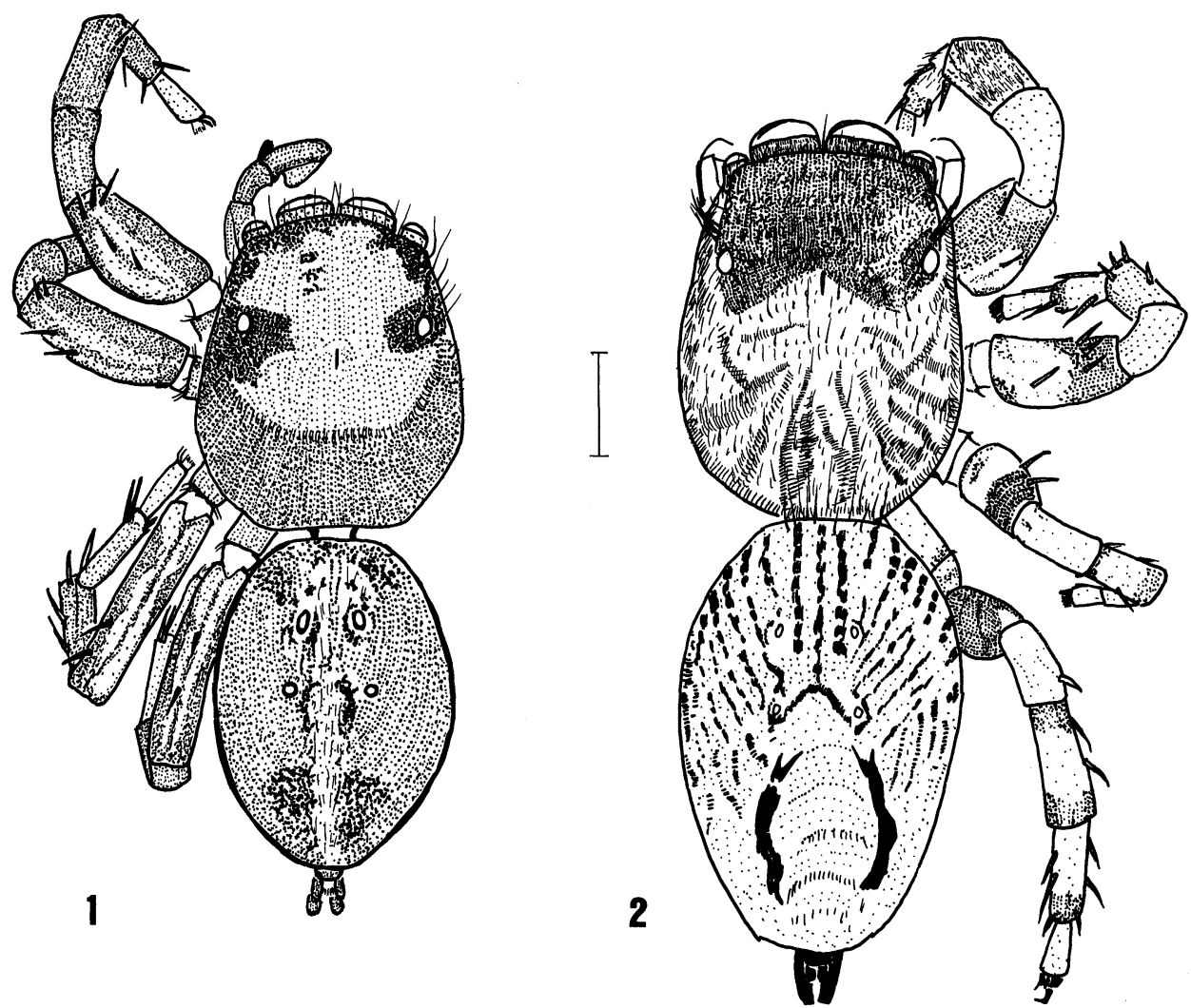

Figs. 1-2. Evarcha fasciata SEO, 1992. -1, Male, dorsal view; 2, female, dorsal view. (Scale: $0.5 \mathrm{~mm}$.)

-1996, S. SAITo leg. (NSMT-Ar 3557); 1 o 2 subadult 우, same locality and collector, 22-IV-1996, 1 ㅇ molted to adult on 3-VI-1996 (NSMT-Ar 3558); 1 subadult 우, 19-XI -1995, 우 molted to adult on 19-VI-1996 (NSMT-Ar 3559); 1 శ , 13-V-1996(NSMTAr 3560); 1 ð ,7-X-1995 (NSMT-Ar 3561).

Other specimens examined. 1 이 1 우, Daisho-ji, Kaga-shi, Ishikawa Pref., 1-VI1996, S. SAITo leg.; 1 이 1 우, Un'na-bashi, Tenryu-shi, Shizuoka Pref., 25-V-1994, Y. ITAKURA leg.; $1 \sigma^{7}$, Kyogamine, Toyoda-shi, Aichi Pref., 12-V-1992, K. OGATA leg.; 1 우, Kada, Shitara-cho, Kitashitara-gun, Aichi Pref., 5-V-1991, K. OGATA leg.; 1 우, same locality and collector, 12-VI-1994; 1 శ $\sigma^{7}$, Kushida-gawa, Matsuzaka-shi, Mie Pref., 7-X-1995, M. EgUCHI leg.; 2 ð , Kokubu-cho, Suzuka-shi, Mie Pref., 3-V-1980, A. UYEMURA leg.; 1 우, Hoshiya, Wakayama-shi, Wakayama Pref., 12-VI-1975, K. YAMAGISHI leg.; 1 우, Masuda-shi, Tottori Pref., 1-VI-1980, S. NAOMI leg.; $1 \sigma^{7}$, Shinpon, Soja-shi, Okayama Pref., 3-X-1991, K. NoJIMA leg.; 1 ठ shi, Okayama Pref., 6-X-1992, K. NoJIMA leg.; 2 o , Kawaguchi, Saidaiji, Okayama-shi, Okayama Pref., 15-IX-1994, K. NoJIMA leg.; $1 \sigma^{7}$, Shimoyama, Aida-cho, Aida-gun, Okayama Pref., 29-IV-1990, K. NoJIMA leg.; 1 ð , Kinkaienden, Oku-cho, Oku-gun, Okayama Pref., 8-V-1993, K. NoJIMA leg.; 2 우, Shinjo, Sadowara-cho, Miyazaki-gun, 

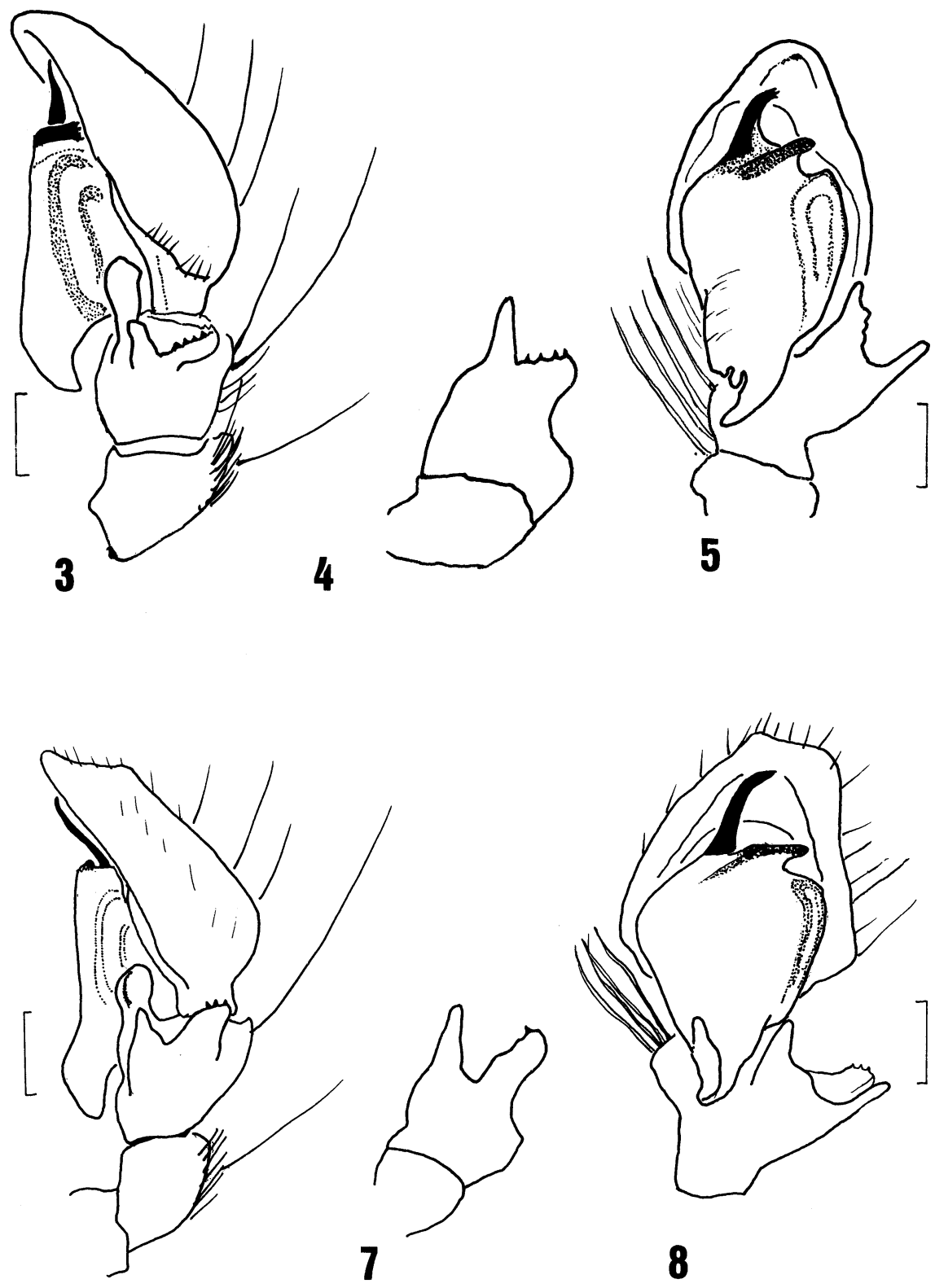

6

Figs. 3-8. 3-5, Evarcha fasciata SEO, 1992; 6-8, Evarcha albaria (L. KoCH, 1878).-3, 6, Male palps, retrolateral view; 4, 7, RTA of male palps, proximal view; 5, 8; male palps, ventral view. (Scales: $0.2 \mathrm{~mm}$.) 
Miyazaki Pref., 20-VI-1993, T. IsHINODA leg.; $1 \sigma^{7}$, same locality and collector, 5-XII -1993; 1 오, Fukiagehama, Higashiichiki-cho, Hioki-gun, Kagoshima Pref., 22-VIII1989, A. TANIKAWA leg.

Comparative specimens examined. Evarcha albaria (L. KocH, 1878) - 1 의 1 우, Yatsuda, Chiba-shi, Chiba Pref., 12-XII-1993, M. SADAmoto leg. (NSMT-Ar 3562); 3 o 2 우, Tachibana-yama, Fukuoka-shi, Fukuoka Pref., 17-V-1974, K. YAMAGISHI leg. (NSMT-Ar 3563); 2 이 3 우, same locality and collector, 8-14-VII-1979 (NSMT-Ar 3564); many other specimens from various areas of Japan, from Hokkaido to Yakushima Island.

Description. Measurement of the specimens (NSMT-Ar 3557) from Fukui Pref. (in $\mathrm{mm}$; variation of other specimens in parentheses). Body length o7 $6.84(6.20-7.14)$, 우 7.50 (5.47-7.50); prosoma length o 3.34 (3.07-3.47), 우 3.83 (3.60-3.83), width ơ 2.59 (2.27-2.77), 우 2.93 (2.83-3.00), height or 1.42 (1.42-1.66), 우 1.67 (1.47-1.67); opisthosoma length o 3.50 (3.20-3.67), 우 3.87 (3.87-5.54), width ơ 2.54 (2.17-2.60), 우 2.90 (2.83-2.90). Eye field: ALE-ALE 이 2.03 (1.90-2.03), 우 2.17 (2.16-2.17), PLE-PLE 구 2.14 (2.02-2.14), 우 2.29 (2.27-2.29), ALE-PLE 이 1.31 (1.13-1.31), 우 1.33 (1.27-1.33), ALE-PME o 0.64 (0.61-0.64), 우 0.67 (0.56-0.67), ALE-ALE/PLE-PLE < 1.0. AME diameter o 0.54 (0.54-0.58), 우 0.63 (0.58-0.63). ALE/AME ơ 0.55 (0.49-0.55), 우 0.50 (0.50-0.53), ALE/PLE ơ 1.20 (1.06-1.20), 우 1.06 (1.00-1.14), PME/PLE ơ 0.27 (0.25-0.27), 우 $0.28(0.28)$. Chelicera with one retromarginal tooth (male and female).
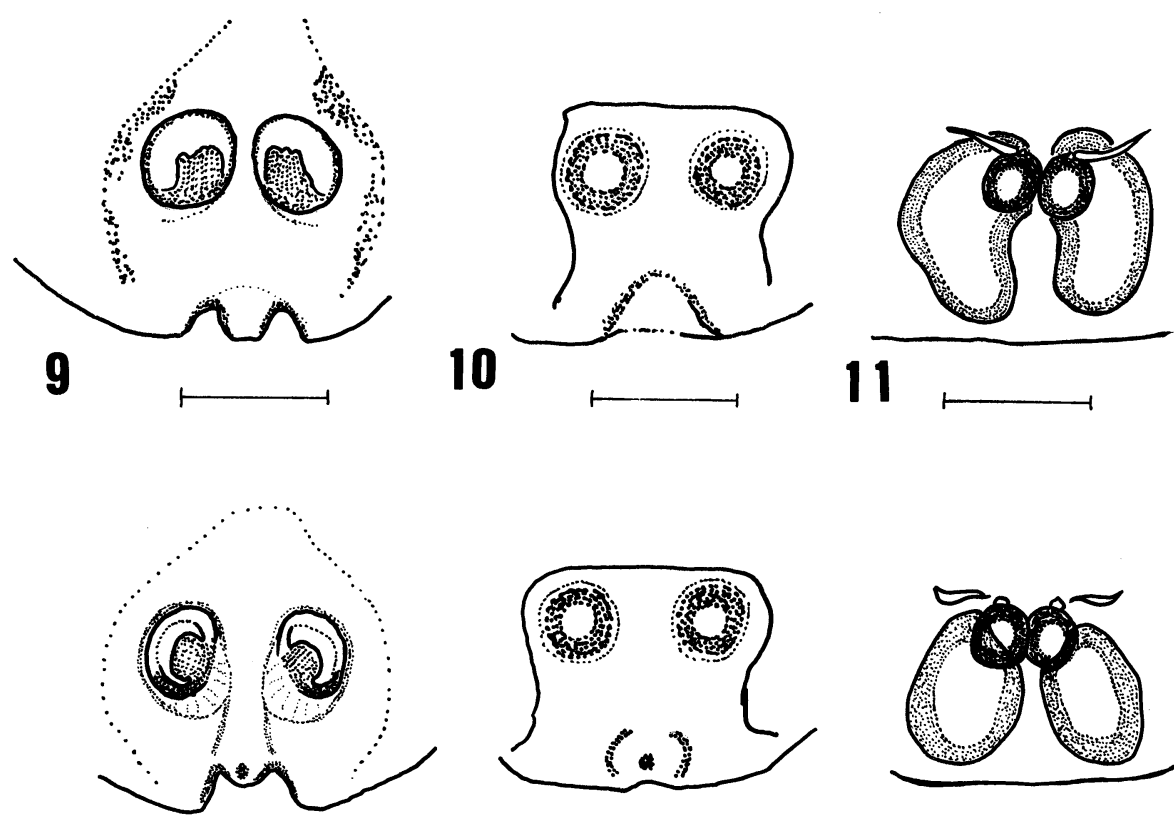

\section{2}

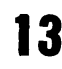

\section{4}

Figs. 9-14. 9-11, Evarcha fasciata SEO, 1992; 12-14, Evarcha albaria (L. KoCH, 1878). 9, 12, Epigynum; 10, 13, female genitalia, posterior view; 11, 14, same, dorsal view. (Scales: $0.2 \mathrm{~mm}$.) 
Table 1. Measurement of leg segments of Evarcha fasciata (ð/우; in mm).

\begin{tabular}{ccccccc}
\hline Leg & Femur & Patella & Tibia & Metatarsus & Tarsus & Total \\
\hline I & $2.00 / 2.14$ & $1.25 / 1.23$ & $1.63 / 1.74$ & $1.04 / 0.93$ & $0.63 / 0.67$ & $6.55 / 6.71$ \\
II & $1.88 / 2.14$ & $1.21 / 1.15$ & $1.29 / 1.50$ & $0.83 / 0.93$ & $0.63 / 0.67$ & $5.84 / 6.39$ \\
III & $2.30 / 2.43$ & $1.12 / 1.31$ & $1.25 / 1.42$ & $1.20 / 1.33$ & $0.75 / 0.73$ & $6.62 / 7.22$ \\
IV & $2.00 / 2.30$ & $0.93 / 1.20$ & $1.34 / 1.42$ & $1.34 / 1.52$ & $0.73 / 0.73$ & $6.34 / 7.17$ \\
\hline
\end{tabular}

Table 2. Spination of legs of Evarcha fasciata (dorsal/ventral; none $=$ no spine, $\mathrm{r}=$ retrolateral, $\mathrm{p}=$ prolateral).

\begin{tabular}{|c|c|c|c|c|}
\hline Leg & Femur & Patella & Tibia & Metatarsus \\
\hline \multirow[t]{2}{*}{ I } & オ $0-1-1-1 \cdot 2 \mathrm{p} \cdot 1 \mathrm{r} /$ none & lp/none & $1 p-0-1 p-0 / 2-2-2$ & none/2-2 \\
\hline & 우 $0-1-1-1 \cdot 2 \mathrm{p} \cdot 1 \mathrm{r} /$ none & $1 \mathrm{p} /$ none & $1 p-0-1 p-0 / 2-2-2$ & none $/ 2-2$ \\
\hline \multirow[t]{2}{*}{ II } & 万 $0-1-1 \mathrm{r}-1 \cdot 2 \mathrm{p} \cdot 1 \mathrm{r} /$ none & $1 \mathrm{p} /$ none & $1 \mathrm{p}-0-1 \mathrm{p}-0 / 2-2-2$ & none $/ 2-2$ \\
\hline & 우 $0-1-1-1 \cdot 2 \mathrm{p} \cdot 1 \mathrm{r} /$ none & $1 \mathrm{p} /$ none & $1 p-0-1 p-0 / 2-2-2$ & none $/ 2-2$ \\
\hline \multirow[t]{2}{*}{ III } & 万 $0-1-1 \cdot 1 \mathrm{p}-1 \cdot 2 \mathrm{p} \cdot 1 \mathrm{r} /$ none & $2 /$ none & $2-2-2-0 / 0-1 \mathrm{p}-2$ & $2-2 / 1 p-2 p \cdot 2 r$ \\
\hline & 우 $0-1-1 \mathrm{p}-1-1 \cdot 2 \mathrm{p} \cdot 1 \mathrm{r} /$ none & $2 /$ none & $2-2-2-0 / 0-1 \mathrm{p}-2$ & $2-2 / 2-2 p \cdot 2 r$ \\
\hline \multirow[t]{2}{*}{ IV } & व $0-1-1-3 /$ none & $2 /$ none & $2-2-2-0 / 0-1 \mathrm{p}-2$ & $2-2-2 / 2-2 p \cdot 2 r$ \\
\hline & 우 $0-1-1-3 /$ none & $2 /$ none & $2-2-2-0 / 0-1 \mathrm{p}-2$ & $2-2-2 / 2-2 p \cdot 2 r$ \\
\hline
\end{tabular}

Length of legs as shown in Table 1.

Spination of legs of the same specimens as shown in Table 2.

Male palp (Figs. 3-5). Three-pronged RTA characteristic. Median and dorsal projections of RTA L-shaped from proximal view. Cymbium brown with white setae, femur, patella and tibia black.

Female genitalia (Figs. 9-11). Epigynum simple with a narrow septum between the copulatory openings, frequently plugged after mating. Spermathecae large and ovate.

Coloration and markings (Figs. 1-2). Male: Prosoma blackish brown covered with black hairs, surroundings of eyes black with black hairs, anterior margin black with black setae, and a tuft of several setae present below PME. AME and ALE surrounded with brown hairs. Slope of thoracic part with dense transparent hairs. Clypeus blackish brown with black setae. Sternum blackish brown covered with white hairs and short black hairs. Chelicera and labium black. Maxilla blackish brown with light margins. Opisthosoma: dorsum black with black setae on anterior margin and with a biramous longitudinal marking with white hairs and wholly covered with brown and black hairs; venter black, covered with black hairs. Spinnerets black. Legs I and II: femur, tibia and metatarsus black, patella paler, tarsus brown. Legs III and IV: femur, patella and tibia black, metatarsus blackish brown or brown, tarsus brown.

Female: Prosoma blackish brown but paler than male, covered with black and white hairs, scattered with black and white setae, cephalic part dark blackish brown, surroundings of eyes black with white hairs, and a tuft of several setae present below PME. AME and ALE surrounded with brown and white hairs. Thoracic part blackish brown with radial black pigments. Slope of thoracic part with white setae and white hairs. Clypeus brown with white setae. Sternum brown with white hairs and short black hairs. Labium and maxilla brown with light margins. Chelicera brown. Opisthosoma: dorsum black covered with dense brown and white hairs, scattered with black and white setae, anterior part with many black setae; venter black with a pair of 
Table 3. Comparison between characteristics of Evarcha fasciata and E. albaria

\begin{tabular}{|c|c|c|}
\hline Species & Evarcha fasciata & E. albaria \\
\hline \multicolumn{3}{|l|}{ Male } \\
\hline $\begin{array}{l}\text { Prosoma } \\
\text { cephalic part }\end{array}$ & $\begin{array}{l}\text { black without } \\
\text { white hairs }\end{array}$ & $\begin{array}{l}\text { black with } \\
\text { belt of white hairs }\end{array}$ \\
\hline $\begin{array}{l}\text { Prosoma index } \\
\quad(\text { width/length } \times 100)\end{array}$ & $78-85$ & $73-75$ \\
\hline ALE-ALE/PLE-PLE & $<1.0$ & $>=1.0$ \\
\hline Length of legs & III $>$ I $>$ IV $>$ II & III $>$ IV $>$ I $>$ II \\
\hline $\begin{array}{l}\text { Median and dorsal } \\
\text { projections of RTA of palp }\end{array}$ & L-shaped & V-shaped \\
\hline \multicolumn{3}{|l|}{ Female } \\
\hline $\begin{array}{l}\text { Prosoma: radial black } \\
\text { pigments on } \\
\text { thoracic part }\end{array}$ & present & $\begin{array}{l}\text { absent } \\
\text { or scarce }\end{array}$ \\
\hline $\begin{array}{l}\text { Prosoma index } \\
\quad(\text { width } / \text { length } \times 100)\end{array}$ & $77-80$ & $75-80$ \\
\hline ALE-ALE/PLE-PLE & $<1.0$ & $>=1.0$ \\
\hline $\begin{array}{l}\text { Epigynum: width of } \\
\text { median septum }\end{array}$ & narrow & wide \\
\hline $\begin{array}{l}\text { Legs: Length of } \\
\text { metararsus }\end{array}$ & IV $>$ III & $\mathrm{IV}<\mathrm{III}$ or $\mathrm{IV}=\mathrm{III}$ \\
\hline
\end{tabular}

longitudinal gray dots, covered with brown and white hairs. Spinnerets black. Legs I and II: femur brown with black distal and dorsal proximal parts, patella brown, tibia blackish brown, metatarsus brown with black distal part, tarsus brown. Legs III and IV: same as leg I except metatarsus with proximal and distal parts black.

Mating behavior. The pairs as below were mated in a small wooden box in the laboratory in June, 1996: 이 (NSMT-Ar 3557) × 우 (NSMT-Ar 3557), 이 (NSMT-Ar $3558) \times$ 우 $($ NSMT-Ar 3559), 이 (NSMT-Ar 3560) $\times$ 우 (NSMT-Ar 3558). The mating behavior observed in one pair was as follows. The male raised up his first legs and began his display toward the female. She firstly escaped from him and then stopped, gazed him. About 10 minutes later, she crouched. Finally when facing each other, he quickly proceeded, mounted her and copulated. It took approximately 8 minutes to finish copulation. The mating behavior of the other two cases was similar to this pair.

Distribution. Japan (Honshu,Kyushu), Korea and China.

Remarks. Evarcha fasciata SEO, 1992, closely resembles Evarcha albaria L. КоCH, 1878, but can be distinguished from the latter by the color pattern, ALE-ALE/PLEPLE, the hair, the shape of the tibial apophysis of male palp, the width of median septum of epigynum and the length of metatarsus of leg III and IV. SEO (1992) pointed out that the carapace index (prosoma wide/length) is important for identification of male. This index is not adequate for female identification, because it varies from 77 to 80 in Japanese population, which is very similar to that of Evarcha albaria. (Table 3).

\section{Acknowledgements}

We wish to express our hearty thanks to Dr. Hirotsugu ONO, National Science Museum (Nat. Hist.), Tokyo, for his constant guidance and for critically reading the manuscript of this paper, and to Mr. Ken-ichi KumadA, Miyagi, Mr. Akira SHINKAI, Tokyo, Mr. Fumio SASAOKA, Tokyo, Mr. Miyoshi SADAmoto, Chiba, Mr. Shigeo 
Suzuki, Chiba, Mr. Akio TANIKAwa, Kanagawa, Mr. Mitsuru BAN, Kanagawa, Mr. Yoshimasa Goto, Kanagawa, Mr. Kiyoto OgatA, Aichi, Mr. Yasuhiro ITAKURA, Aichi, Dr. Nobuo TsuruSAKI, Tottori, Mr. Ko-ichi NoJIMA, Okayama, late Dr. Chiyoko OKUMA, Fukuoka, and Mr. Takeo IsHINODA, Miyazaki, for offering or loaning the specimens used in this paper.

摘要

韓国で記載された Evarcha 属の 1 種 Evarcha fasciata SEO, 1992 マミクロハエトリ(新 称）を日本から報告した。本種は千国（1989）がマミジロハエトリの 1 種（A）として図 鑑に掲載している種と同種であるが，メスはこれまで詳細に記載されたことはなかった ので，交配実験により確認した雌雄の個体を記載した。なお，本種は既知の Evarcha albaria（L. KOCH，1878） マミジロハエトリによく似ているので比較対照した．両種は それぞれ色彩・斑紋, 頭胸部前端の白毛の有無, 前側眼列幅と後側眼列幅の比, 生殖器 の構造, 歩脚の一部（第 III 脚と第 IV 脚の蹠節）の相対長によって識別できる.オスで の識別は容易だが，メスの識別は注意を要する.

\section{References}

ChIKUNI, Y.,1989. Pictorial Encyclopedia of Spiders in Japan. 308pp. Kaisei-sha, Tokyo. (In Japanese.)

SEO, B. K., 1992. A new species of genus Evarcha (Araneae: Salticidae) from Korea (II). Korean Arachnol., 7: 159-162.

Xianjin, P., X. LiPING, \& J. P. Kim, 1993. Study on the spiders of the genus Evarcha (Araneae: Salticidae) from China. Korean arachnol., 9: 7-18.

Xianin, P., X. Liping, \& X. XiaOQuin, 1993. Salticids in China. 270 pp. Hunan Normal Univ. Press. 